Article

\title{
The Potential Use of Agroforestry Community Gardens as a Sustainable Import-Substitution Strategy for Enhancing Food Security in Subarctic Ontario, Canada
}

\author{
Nicole F. Spiegelaar *, Leonard J.S. Tsuji and Maren Oelbermann \\ Department of Environment and Resource Studies, University of Waterloo, Waterloo, ON N2L 1G3, \\ Canada; E-Mails: 1jtsuji@uwaterloo.ca (L.J.S.T.); moelbermann@uwaterloo.ca (M.O.) \\ * Author to whom correspondence should be addressed; E-Mail: nicolespieg@gmail.com; \\ Tel.: +1-519-888-4567 (ext. 32762); Fax: +519-746-0292.
}

Received: 10 August 2013; in revised form: 7 September 2013 / Accepted: 10 September 2013 / Published: 23 September 2013

\begin{abstract}
The high prevalence of food insecurity experienced by northern First Nations partially results from dependence on an expensive import-based food system that typically lacks nutritional quality and further displaces traditional food systems. In the present study, the feasibility of import substitution by Agroforestry Community Gardens (AFCGs) as socio-ecologically and culturally sustainable means of enhancing food security was explored through a case study of Fort Albany First Nation in subarctic Ontario, Canada. Agroforestry is a diverse tree-crop agricultural system that has enhanced food security in the tropics and subtropics. Study sites were selected for long-term agroforestry research to compare Salix spp. (willow)-dominated AFCG plots to a "no tree" control plot in Fort Albany. Initial soil and vegetative analysis revealed a high capacity for all sites to support mixed produce with noted modifications, as well as potential competitive and beneficial willow-crop interactions. It is anticipated that inclusion of willow trees will enhance the long-term productive capacity of the AFCG test plots. As an adaptable and dynamic system, AFCGs have potential to act as a more reliable local agrarian system and a refuge for culturally significant plants in high-latitude First Nation socio-ecological systems, which are particularly vulnerable to rapid cultural, climatic, and ecological change.
\end{abstract}

Keywords: subarctic First Nations; climate change; food security; adaptation; agroforestry; import substitution; sustainability 


\section{Introduction}

\subsection{Food Security in Sub-Arctic First Nations}

The Euro-Canadian Roman Catholic Mission developed agrarian settlements in remote First Nations of Northern Canada in the early 20th century [Vezina, unpublished manuscript, Historical Notes on the Village of Attawapiskat, Roman Catholic Church: Attawapiskat, Ontario], forcing nomadic indigenous peoples to settle and displacing traditional aboriginal ways of acquiring food [1,2]. In a previous study [2], Spiegelaar and Tsuji discuss extensively pre- and post- settlement socio-ecological and cultural conditions in remote First Nations communities. The Mission was somewhat successful in producing diverse foods within a challenging environment and short growing season, but their departure and subsequent closing of residential schools in the late 20th century ended local agricultural production and left remote First Nations dependent on an unreliable, import-based food system [2]. Modern food systems in these remote First Nations often lack nutritional quality [3-6], bear high transportation costs, and perpetuate the loss of traditional Aboriginal food systems and associated knowledge [7], ultimately impacting individual and community health [8]. This import-based system is also extremely resource-intensive, while it simultaneously perpetuates reliance on the unstable fossil-fuel industry and global food economy $[9,10]$. Modern First Nation food systems, therefore, prevent these vulnerable populations from becoming food secure [8]. Food Security can be defined as follows: the "access by all people at all times to enough food for an active, healthy life...[including] the ready availability of nutritionally adequate and safe foods, and an assured ability to acquire acceptable foods in socially acceptable ways" [11].

\subsection{Subarctic Agriculture}

A re-introduction of local agriculture to augment traditional Aboriginal foods in northern communities has been suggested as a means to partially substitute imports, enhance food freshness, variety and nutrition, increase local control over food availability, and ultimately, increase food security [2]. While productivity in northern ecosystems is relatively limited, the capacity for food production in subarctic and arctic zones continues to increase with a warming climate; researchers predict an increase in the length of the growing season, enhanced plant growth rates, and greater soil nutrient availability in the north, and in turn, more hospitable conditions for growing a greater variety of edible plants [12]. Although increased productivity will subsequently increase carbon sequestration in biomass of high-latitude systems, the net effect will be a positive feedback towards warming due to significant levels of carbon release from permafrost thawing in the north [12,13]. While promising for northern food production, these rapid climatic and ecological changes are threatening wildlife and traditional ecological resources in these regions $[14,15]$. Wide-scale spread of conventional agriculture to the north could perpetuate the climate change problem.

Modern agricultural methods release large amounts of $\mathrm{CO}_{2}$ and $\mathrm{N}_{2} \mathrm{O}$ through heavy use of industrial machinery and chemical fertilizers [16]; they also require extensive forest clearing followed by intensive land management, resulting in losses of carbon stores from both above-ground biomass and soil organic carbon [17]. Conventional agriculture has also been associated with short-term returns and long-term land degradation. Strategies used in this modern farming practice focus on increasing yield 
through high use of pesticides and herbicides, and are dependent on expensive, resource-intensive technology [9,17]. Throughout North America, conventional agriculture has resulted in vast displacement of native biodiversity, land degradation and pollution of land and water [17,18].

Our previous study [2] on food security in the remote First Nation of Fort Albany, located in the James Bay Lowlands of subarctic Ontario, explored the successes, failures and long-term impacts of the Roman Catholic Mission's agricultural program (1940-1970) on the local land and food system. In sum, a somewhat reliable food source was developed, but land cultivation introduced invasive species and resulted in significant soil quality loss, while the program aggressively displaced the traditional aboriginal harvest [2]. The agrarian program left with the Mission in the 1970s, when the residential school closed. As a result, First Nation people became more dependent on unhealthy store imports because neither the agrarian settlement nor the fragments of a nomadic indigenous tradition could support them. In a region with limited arable land that is vulnerable to rapid climatic, ecological and social change, conventional agricultural and food assistance programs are short-term solutions that ultimately degrade community culture and land resources. Yet, as First Nation populations continue to increase at a rate greater than the general Canadian population [19], and climate change provides more hospitable temperatures for northern crop production [12], import-substitution strategies other than conventional agriculture need to be explored.

\subsection{Agroforestry}

Agroforestry is an alternative land-use system to conventional agriculture that has been utilized as a socioeconomically and ecologically sustainable means to establish long-term food security in impoverished areas, mainly within the sub-tropic and tropic regions [20,21]. Simply, it is a relatively recent term for an ancient practice of agriculture, which by definition, is a land-use system that combines woody perennials (e.g., trees, shrubs) with crops in spatial and temporal arrangements that optimize beneficial biological interactions and economic outputs [17,18].

In contrast to conventional agriculture, the use of multiple components and multiple species in agroforestry systems maintains ecological diversity [17]. Agroforestry systems in the tropics, sub-tropics and temperate regions (e.g., China) have played a substantial role in enhancing food security, as low input systems with diverse and complementary food products [17,22-24]. The reduced mechanical intervention allows for maintenance of soil integrity and more closed nutrient-cycling [18], subsequently, reducing the need for expensive and ecologically-damaging chemical inputs [25] and the emissions of $\mathrm{N}_{2} \mathrm{O}$ and $\mathrm{CO}_{2}$ [16]. As potential carbon sinks, northern agroforestry systems may act as an adaptive response to climate change in contrast to conventional agriculture, in both mitigating carbon dioxide and adapting to anticipated ecological changes $[25,26]$.

Agroforestry started re-appearing in North America in the 1980 s with the realization of the economically, socially, and ecologically unsustainable nature of conventional agriculture [17]. However, agroforestry practices in temperate, industrialized countries tend to focus on few, highly-valued crops as to improve the economic profitability of farms, rather than meeting subsistence needs [27]. Nevertheless, even in temperate systems, inclusion of trees in agriculture has proven to increase yield via wind protection and control of soil erosion [17]. However, agroforestry has not been widely applied in temperate regions as a means to address food security, and no known use of agroforestry in 
the subarctic or arctic regions has been documented. As Gordon and Newman [17] argue, research of the feasibility of transferring these systems to other regions is necessary.

\subsection{Study Objectives}

In the present study, we explored the feasibility of introducing agroforestry to an isolated subarctic First Nation by: (1) designing long-term agroforestry study plots in a case study community and; (2) determining site fertility and potential soil modifications necessary for implementing these test plots. Implementation of agroforestry test plots in the case study community would allow for long-term studies of agroforestry as a potential sustainable food localization strategy to enhance food security in northern First Nations in light of climate change.

\section{Methods}

\subsection{Case Study Area: Fort Albany First Nation}

Fort Albany First Nation $\left(52^{\circ} 15^{\prime} \mathrm{N} ; 81^{\circ} 35^{\prime} \mathrm{W}\right)$ is an Omushkego Cree community of about 850 people. It is located along the Albany River approximately $20 \mathrm{~km}$ from the western coast of James Bay, Ontario, Canada (Figure 1), and is situated in one of the largest wetland and muskeg areas of the world $[28,29]$. Traditionally, the Cree were nomadic people who relied heavily on wild game and some berries, roots, and tree boughs [2]. In the 1930s, the Roman Catholic Mission operated a residential school in Fort Albany which included a conventional agricultural initiative meant to replace the traditional food system; when the Mission left with the closure of the residential school in the 1970s, this was essentially the end of the agrarian movement in this region [2]. However, with climate change disproportionately impacting this subarctic region, a significant warming trend has been reported [30]; there exists an opportunity to re-introduce a more sustainable agrarian initiative that does not try to replace the traditional food system, but rather complement it.

Figure 1. Map of James Bay and the Surrounding James Bay Region, including the Study Site, Fort Albany First Nation.

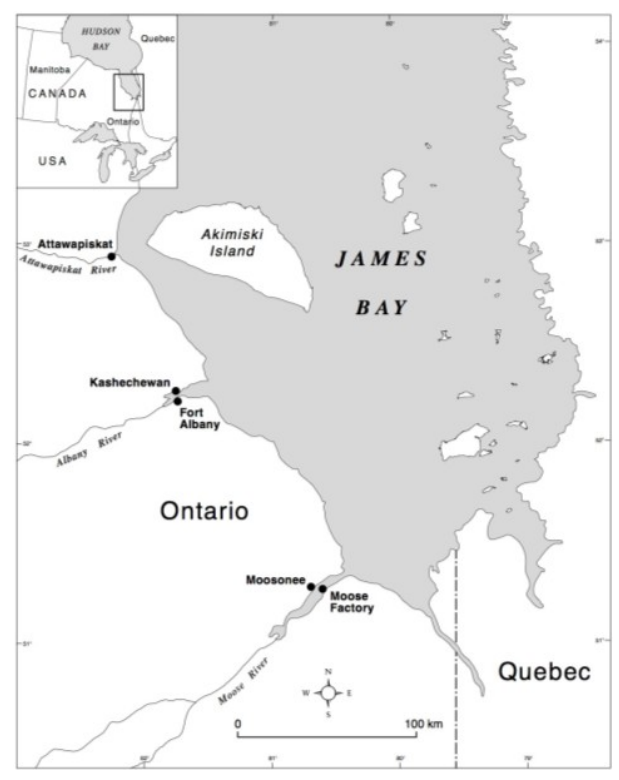




\subsection{Agroforestry Design}

There are several types of agroforestry systems, but there is no term for a community, subsistence agroforestry system. Thus, the concept of an "Agroforestry Community Garden" (AFCG) has been coined here. Aspects of other agroforestry systems can be used to develop a suitable design for the AFCG to meet the needs of subarctic communities. For example, the benefits of subsistence production of diverse, nutritious foods by homegardens, and the ability of tree-based intercropping and shelterbelt systems to protect crops from harsh weather conditions, and sequester carbon, are functions desirable for AFCGs in remote First Nations. Thus, agroforestry homegarden, tree-based intercropping and shelterbelt system designs were identified as potential design contributors to AFCGs.

In agroforestry literature, the term "homegarden" refers to "landuse practices involving deliberate management of multipurpose trees and shrubs in intimate association with annual and perennial agricultural crops... within the compounds of individual houses" [31]. While the term is often used in other literature to describe any gardens adjacent to the household, homegarden will be used here strictly to refer to gardens that include the tree or shrub component. Homegardens are the primary agroforestry system used for subsistence production and enhancing food security, especially in areas where food cost and distribution are barriers to proper nutrition [22,31]. Homegardens include ecologically adapted and complementary species and are marked by low capital and labour input, simple technology and high productivity [21,22]. The FAO [24] emphasizes the role of homegardens in producing direct access to a diversity of nutrient rich foods and complementary food sources during seasonal lean periods. Northern homegardens could potentially support traditional Aboriginal food systems, if crop activities complement seasonal hunting and fishing.

Shelterbelts or windbreaks are linear plantings of trees or shrubs that provide wind and snow protection, and changes microclimate in adjacent crop areas [17,32]. Within the protected area, this can improve crop quality and crop yields [17,32]. Shelterbelts are useful in cold climates to protect crop from wind stress [17]. In northern areas, properly designed shelterbelts can assist in uniform snow distribution across a field, making more moisture available to crops [17,32]. They can also be used to protect homes from extreme weather conditions [17]. Shelterbelts can also be used as significant carbon sinks; a 0.4 ha field windbreak is said to store over 21 metric tons of carbon dioxide in the trees by age 20 [32].

Tree-based intercropping or "alley cropping" involves planting several crops together in strips or alleys between hedgerows of trees and shrubs [17,25]. The trees can be used to modify micro-climate, protect crops from winds (reducing water loss), and reduce soil erosion [17,25,33]. Tree-based intercropping differs from shelterbelts, however, in that the trees themselves provide products of socioeconomic value, such as, fruit, biofuel, fodder or timber, and thus may differ in species, location and density [17]. Several rows of trees can also provide litter to protect the soil surface, prevent night chilling and frost damage, recycle nutrients, replenish soil organic matter, and provide carbon substrates for soil biota [33,34]. These functions may have a place in subarctic regions, where the climate is harsh, arable land is limited and conventional agriculture has degraded soil organic matter and nutrient content [2]. The tree row is capable of extracting nutrients at deeper horizons that would have otherwise been leached, and return them back to the soil through leaf litter for use by crops [17]. 
However, intercropping trees may also compete for radiation (especially in the northern hemisphere) nutrients or soil moisture [34].

\subsection{Agroforestry Site Selection}

Study sites within Fort Albany were selected based on Agroforestry design and interviews with Fort Albany community members. Interviewees were asked if they approved the study plots and consulted on the ideal location based on accessibility, known soil quality, land-use history, future land-use, and personal preference.

Fort Albany community members identified the fields previously cultivated by the Mission in the 20th century as an ideal location for a community garden, because of the known productivity of the land, the human-made drainage ditches, the proximity to a freshwater lake, and the absence of difficulties (e.g., dogs, vandalism) associated with previous garden initiatives in the town centre [2]. Based on the community preferences and experiences, as well as design considerations, three sites (A, B and C) were chosen for long-term AFCG studies. An undisturbed forest control test plot was also investigated with results presented elsewhere [2].

"AFCG" Site A and B are located within the previously cultivated area being easily accessed from the road and already support growth of maturing Salix spp. (willow) trees (Figure 2). The willows, which now dominate the old drainage ditches, border these two sites, allowing for immediate introduction of the AFCG, and the use of naturally existing and adapted tree species. With parallel rows of willow tree species, this location is ideal for research on tree-based intercropping or shelterbelt community gardens with homegarden components incorporated. The use of two sites will allow for long-term research of different management strategies for optimal crop production, because the trees rows differed in terms of willow maturity and density. "No Tree" Site C is also located within the historically cultivated area, but lacks invasion of willow trees being selected as a control (Figure 2). No trees or shrubs are growing within a $58 \mathrm{~m}$ radius of this site. Introduction of a community garden on this site, followed by continued research of productivity in this "No Tree" site and the AFCG sites will provide valuable information on the effect of willow trees in subarctic gardens; this will assist in determining the suitability of AFCGs in the subarctic over the long-term.

\subsection{Plant Species Composition}

Plant species within the sites were identified to characterize undisturbed and disturbed ecology of the area, provide insight on management history, and characterize initial site conditions [34] prior to garden implementation and long-term AFCG studies. Dominant species surrounding these sites were also identified to characterize the local ecosystem [34].

\subsection{Soil Sampling Design}

An inventory study is a general type of soil testing to measure the amount of a variable under study and is used in agroforestry research to determine if soil properties are suitable for growing specific crops [35]. A systematic inventory was used to sample the agroforestry sites (A and B); while, a random inventory was used to sample the "no tree" Site C. A systematic grid, soil-sampling design 
(Site A, $n=18$; Site B, $n=18$; Figure 2) was developed to cover long-term soil property changes in relation to the tree component, crop placement, and other geographic factors. Tree-crop interactions may be complementary, neutral or competitive in agroforestry systems [18], depending on the species and the environment.

With no tree-crop interactions and a uniform distribution of plants and topography in Site C, spatial dynamics of soil properties of the "no tree" site are not of interest, making few random samples necessary for inventory. Lacking distinct physical borders, a $20 \mathrm{~m}^{2}$ area was chosen for this site; it was then divided into 20 one-square-metre quadrants, from which three quadrants were randomly chosen as sample points (Site $\mathrm{C}, n=3$ ). From the centre of the site, Site $\mathrm{C}$ was located $58 \mathrm{~m}$ from any tree or shrub.

Figure 2. Proposed Agroforestry Community Garden Sites (Sites A and B, between Salix sp. rows) and a "No Tree" Control Site (Site C, in an open field) in Fort Albany First Nation, Ontario.

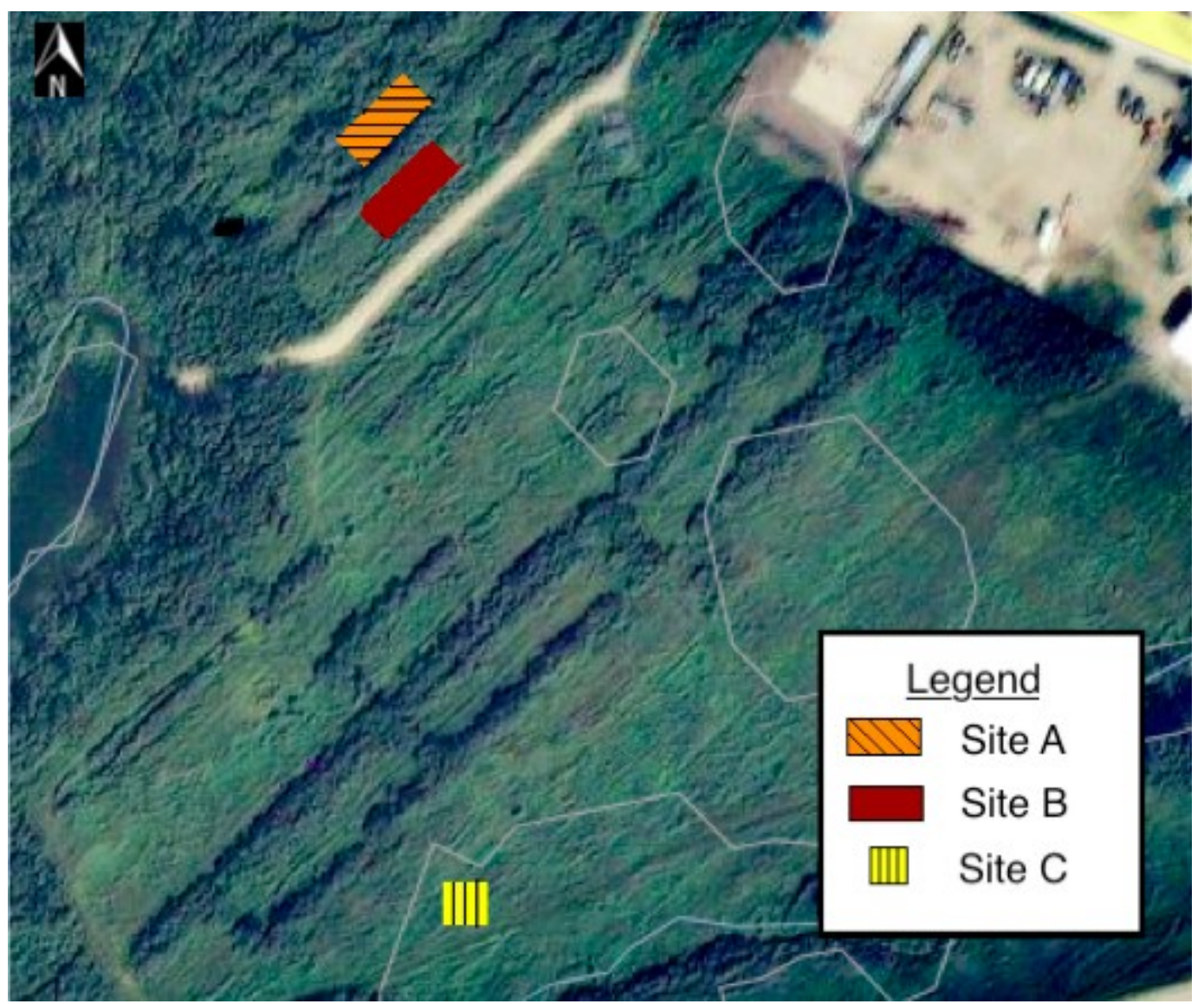

Note: sites not to scale.

\subsection{Soil Sample Collection Methods}

A small soil corer $(20 \mathrm{~cm}$ height $\times 4.5 \mathrm{~cm}$ diameter $)$ was used. Soil samples were taken in the topsoil up to a $20 \mathrm{~cm}$ depth, corresponding to where most available nutrients are found, and where soil is manipulated by tillage [34,36]. At each sample point, three soil-core extractions within a $0.5 \mathrm{~m}$ radius were taken, and then bulked to make one composite sample. In addition, an additional soil sample was taken with a bulk density ring $(5.2 \mathrm{~cm}$ height $\times 4.5 \mathrm{~cm}$ diameter $)$ within the same $0.5 \mathrm{~m}$ 
radius of each sample point. Samples were collected 6-10 August 2010, under favourable conditions (i.e., the ground was not frozen or water-logged) and the growing season had peaked [36].

\subsection{Soil Analysis}

Approximately $50 \mathrm{~g}$ of dry samples were sent to the Soil and Nutrient Analysis Lab at the University of Guelph, Ontario, Canada - an agricultural college - for analysis of soil texture, $\mathrm{pH}$, total nitrogen $(\mathrm{N})$, extractable phosphorus $(\mathrm{P})$, potassium $(\mathrm{K})$, magnesium $(\mathrm{Mg})$, and organic carbon (SOC), using standard protocol. Soil organic matter (SOM) was estimated assuming that 58\% of SOM is SOC [33].

Total $\mathrm{N}$ includes the organic form (ON) tied up in SOM and the mineralized forms (IN) usable to plants, as ammonium $\left(\mathrm{NH}_{4}{ }^{+}\right)$or nitrate $\left(\mathrm{NO}_{3}{ }^{-}\right)$[37]. Canadian agriculturalists are interested in the amount of $\mathrm{N}$ fertilizer (inorganic nitrogen) that needs to be added to soil for given crops because $\mathrm{N}$ forms have high spatial and temporal variability within the soil [38] and $\mathrm{N}$ is so frequently the limiting growth factor in conventional agricultural systems [33,36]. Under the assumption that less than $5 \%$ of total $\mathrm{N}$ is inorganic, the amount of IN in samples was estimated and compared to known fertilizer requirements.

Soil texture (percent sand, silt and clay particles) within an area of similar treatment and vegetation is slow to change temporally and spatially [33]; thus, only three samples per plot were analyzed for grain size. Samples from the bulk density ring were used to determine bulk density (BD) and soil moisture (SM) at the University of Waterloo using standard protocol.

\subsection{Data Analyses}

Descriptive statistics of soil properties for the sites were compared to levels of soil properties reported as being optimal for growth of mixed garden produce. Known optimal values of soil $\mathrm{P}, \mathrm{K}, \mathrm{Mg}$ and $\mathrm{pH}$ and fertilizer $\mathrm{N}$ were taken from the Agriculture Analytical Services Lab (AASL) of Penn State University [39]. Optimal values of other soil properties were estimated from several sources.

\section{Results}

\subsection{Species Composition}

Vegetation within Site A consisted of a mix of early pioneer species (Table 1) reaching up to $45 \mathrm{~cm}$ in height, with several dominant species. Vegetation within Site B was a spatially heterogeneous mixture of early pioneer species (Table 1) reaching up to $86 \mathrm{~cm}$ in height, with a few dominant species. Site $\mathrm{C}$ was composed of a spatially heterogeneous mixture of early pioneer species in approximately equal proportions (Table 1).

Betula papyrifera (white birch), Picea glauca (white spruce), Thuja occidentalis (white cedar), Larix laricina (tamarack) and Abies balsamea (balsam fir) were common tree species found in undisturbed forests surrounding the study sites [2]. Aspen was common on the outer edges of the forest. Willows dominated disturbed areas, such as, roadsides and backyards. The most common tree species in the proposed garden area, outside of the study sites, were willow and alder. 
Table 1. Vegetative species identified in the proposed agroforestry community garden sites (Sites A and B) and a "No Tree" Control Site (Site C) in Fort Albany First Nation, Ontario, Canada.

\begin{tabular}{|c|c|c|c|c|}
\hline \multirow{2}{*}{ Site } & \multicolumn{2}{|r|}{ Dominant Vegetation } & \multicolumn{2}{|r|}{ Other Vegetation } \\
\hline & $\%^{\dagger}$ & Species Name & $\%^{\dagger}$ & Species Name \\
\hline $\mathbf{A}$ & 90 & $\begin{array}{l}\text { Agrostis Stolinifera } \\
\text { (creeping bentgrass) } \\
\text { Symphyotrichum lanceolatum } \\
\text { (panicled aster) } \\
\text { Galeopsis tetrahit }{ }^{*} \text { (hemp nettle), } \\
\text { Erysimum cheiranthoides }{ }^{*} \text { (wormseed) } \\
\text { Cirsium arvense }^{*} \text { (Canada thistle) }\end{array}$ & 10 & $\begin{array}{l}\text { Solidago spp. (goldenrod) } \\
\text { Taraxacum officianales }{ }^{*} \text { (dandelion) } \\
\text { Symphyotrichum novae-angliae } \\
\text { (New England aster) } \\
\text { Chenopodium album }{ }^{\star} \text { (pigweed) } \\
\text { Vicia cracca }{ }^{*} \text { (cow vetch) }\end{array}$ \\
\hline B & 80 & $\begin{array}{l}\text { Symphyotrichum lanceolatum } \\
\text { (panicled aster) } \\
\text { Cirsium arvense }{ }^{*} \text { (Canada thistle) }\end{array}$ & 20 & $\begin{array}{l}\text { Solidago spp. (goldenrod) } \\
\text { Vicia cracca }{ }^{*} \text { (cow vetch) } \\
\text { Galeopsis tetrahit }{ }^{*} \text { (hemp nettle) } \\
\text { Erysimum cheiranthoides }{ }^{*} \text { (wormseed) } \\
\text { Taraxicum officianales }{ }^{*} \text { (dandelion) }\end{array}$ \\
\hline $\mathbf{C}$ & & $\begin{array}{l}\text { Symphyotrichum lanceolatum (panicled aster) } \\
\text { Solidago spp. (goldenrod) } \\
\text { Taraxicum officianales }^{*} \text { (dandelion) } \\
\text { Vicia cracca }^{*} \text { (cow vetch) } \\
\text { Cirsium arvense }^{*} \text { (Canada thistle) } \\
\text { Agrostis Stolinifera }^{*} \text { (creeping bentgrass) } \\
\text { Eupatorium maculatum (spotted Joe-Pye weed) }\end{array}$ & & N/A \\
\hline
\end{tabular}

Note ${ }^{\dagger}$ percent coverage of the site; ${ }^{*}$ denotes non-native species.

\subsection{Potential Productivity of Garden Area}

The soil in each site was classified as a silt loam. Compared to the ideal loam texture, the study sites had much lower sand content, more silt, and near the optimal proportion of clay (Table 2). Soil K and $\mathrm{P}$ levels were lower compared to reported optimal levels; while, $\mathrm{Mg}$ levels were much higher and $\mathrm{pH}$ levels were slightly higher, than values reported for optimal mixed garden productivity (Table 2). When compared to optimal range of IN fertilizer additions, the range of estimated IN levels in each site were much higher than crop requirements (Table 3). The estimated structural integrity value ("s"), for each site was well above the critical level, indicating sufficient SOM to maintain soil structure (Table 3). The range of $\mathrm{C}: \mathrm{N}$ and $\mathrm{BD}$ values of each site were less than the maximum critical values crop production (Table 3). Mean moisture levels of each site were higher than optimal levels for agricultural production in a silt loam soil (Table 3 ). 
Table 2. Minimum, mean and maximum values of measured soil properties in proposed agroforestry community garden sites (Sites A and B) and a "No Tree" Control Site (Site C) in Fort Albany First Nation, Ontario, Canada, compared to optimal values of these soil properties for agriculture.

\begin{tabular}{|c|c|c|c|c|c|c|}
\hline Soil Property & Site & $\mathbf{n}$ & Minimum & Mean & Maximum & Optimal Value \\
\hline \multirow{3}{*}{ Sand (\%) } & Site A & 3 & 16.40 & 19.03 & 21.50 & \multirow{3}{*}{40} \\
\hline & Site B & 3 & 17.50 & 19.80 & 22.30 & \\
\hline & Site C & 3 & 13.30 & 17.23 & 22.80 & \\
\hline \multirow{3}{*}{ Silt (\%) } & Site A & 3 & 59.20 & 66.80 & 71.30 & \multirow{3}{*}{40} \\
\hline & Site B & 3 & 61.10 & 62.10 & 62.70 & \\
\hline & Site C & 3 & 65.80 & 66.40 & 67.60 & \\
\hline \multirow{3}{*}{ Clay (\%) } & Site A & 3 & 10.90 & 14.17 & 19.30 & \multirow{3}{*}{20} \\
\hline & Site B & 3 & 15.00 & 18.10 & 20.10 & \\
\hline & Site C & 3 & 11.30 & 16.37 & 19.10 & \\
\hline \multirow{3}{*}{$\mathrm{P}(\mathrm{ppm})$} & Site A & 18 & 8.40 & 15.61 & 27.00 & \multirow{3}{*}{$35-70[39]$} \\
\hline & Site B & 18 & 7.70 & 12.68 & 19.00 & \\
\hline & Site C & 3 & 7.60 & 8.17 & 9.20 & \\
\hline \multirow{3}{*}{$\mathrm{K}(\mathrm{ppm})$} & Site A & 18 & 32.00 & 40.11 & 50.00 & \multirow{3}{*}{ 70-200 [39] } \\
\hline & Site B & 18 & 31.00 & 37.50 & 49.00 & \\
\hline & Site C & 3 & 27.00 & 32.67 & 38.00 & \\
\hline \multirow{3}{*}{$\mathrm{Mg}(\mathrm{ppm})$} & Site A & 18 & 200.00 & 292.22 & 340.00 & \multirow{3}{*}{$100-120$ [39] } \\
\hline & Site B & 18 & 200.00 & 278.89 & 370.00 & \\
\hline & Site C & 3 & 240.00 & 313.33 & 370.00 & \\
\hline \multirow{3}{*}{$\mathrm{pH}$} & Site A & 18 & 7.60 & 7.68 & 7.90 & \multirow{3}{*}{$7[37]$} \\
\hline & Site B & 18 & 7.60 & 7.74 & 8.00 & \\
\hline & Site C & 3 & 7.60 & 7.77 & 7.90 & \\
\hline
\end{tabular}

Table 3. Minimum, mean and maximum values of estimated soil properties in the proposed agroforestry community garden sites (Sites A and B) and a "No Tree" Control Site (Site C) in Fort Albany First Nation, Ontario, Canada, compared to optimal values of these soil properties for agriculture.

\begin{tabular}{c|c|c|c|c|c|c}
\hline Soil Property & Site & $\mathbf{n}$ & Minimum & Mean & Maximum & Optimal Value \\
\hline \multirow{4}{*}{ IN (ppm) } & Site A & 18 & 285.00 & 370.00 & 440.00 & \multirow{3}{*}{$17.5-100[39]$} \\
\cline { 2 - 7 } & Site B & 18 & 260.00 & 326.11 & 380.00 & \\
\cline { 2 - 7 } & Site C & 3 & 140.00 & 288.33 & 395.00 & \\
\hline \multirow{3}{*}{ C:N } & Site A & 18 & 13.40 & 14.46 & 15.34 & \multirow{3}{*}{$<35[40]$} \\
\cline { 2 - 7 } & Site B & 18 & 13.58 & 15.05 & 16.68 & \\
\cline { 2 - 7 } & Site C & 3 & 14.65 & 14.97 & 16.39 & \\
\hline \multirow{3}{*}{$\begin{array}{c}\text { Soil Organic } \\
\text { Matter (\%) }\end{array}$} & Site A & 18 & 14.00 & 17.52 & 21.90 & \multirow{2}{*}{ N/A } \\
\cline { 2 - 7 } & Site B & 18 & 11.67 & 16.07 & 18.97 & \\
\cline { 2 - 6 } & Site C & 3 & 7.52 & 14.14 & 18.97 & \\
\hline
\end{tabular}


Table 3. Cont.

\begin{tabular}{|c|c|c|c|c|c|c|}
\hline Soil Property & Site & $\mathbf{n}$ & Minimum & Mean & Maximum & Optimal Value \\
\hline \multirow{3}{*}{$\begin{array}{l}\text { Soil structural } \\
\text { integrity }\end{array}$} & Site A & 18 & 15.46 & 21.64 & 25.77 & \multirow{3}{*}{$>9[33]$} \\
\hline & Site B & 18 & 14.55 & 20.04 & 22.36 & \\
\hline & Site $\mathrm{C}$ & 3 & 9.08 & 17.08 & 22.91 & \\
\hline \multirow{3}{*}{$\begin{array}{l}\text { Bulk Density } \\
\quad\left(\mathrm{g} / \mathrm{cm}^{3}\right)\end{array}$} & Site A & 18 & 0.56 & 0.66 & 0.74 & \multirow{3}{*}{$<1.4$ [37] } \\
\hline & Site B & 18 & 0.52 & 0.65 & 0.80 & \\
\hline & Site C & 3 & 0.60 & 0.68 & 0.73 & \\
\hline \multirow{3}{*}{$\begin{array}{c}\text { Soil Water } \\
\text { Content (\%) }\end{array}$} & Site A & 18 & 74.95 & 92.22 & 105.92 & \multirow{3}{*}{$\sim 40-45[41]$} \\
\hline & Site B & 18 & 71.88 & 87.57 & 96.85 & \\
\hline & Site $C$ & 3 & 89.73 & 94.45 & 102.94 & \\
\hline
\end{tabular}

\section{Discussion}

\subsection{Species Composition}

The grasses and forbs that dominated the old agricultural fields, Galeopsis tetrahit (hemp nettle), Artemisia cina (wormseed), Cirsium arvense (Canada thistle), Symphyotrichum lanceolatum (panicled aster), and Agrostis Stolinifera (creeping bentgrass) (Table 1), are all pioneer species commonly found on recently exposed sites, such as roadsides, wastelands and cultivated fields as well as the shores of water bodies [42-46]. Being tolerant of a wide variety of soil types and environmental conditions, including high moisture soils, most of these species are highly competitive, with the exception of panicled aster, which is moderately competitive [42-46]. Hemp nettle, wormseed and Canada thistle are non-native and known to be "weedy" or invasive competitors to crops [42-46]. Creeping bentgrass, has been naturalized in North America since 1750 and used as important forage for livestock; it has become "weedy" or invasive in some areas and can often be found with willows as the dominant overstory $[45,46]$. The non-native species, which dominated this area, may have been introduced by the Mission as forage or garden flowers. As highly competitive species, these grasses and forbs may become a threat to successful crop production, especially without the use of chemical herbicides. The maximum height of vegetation in Site A was $41 \mathrm{~cm}$ shorter than that of Site B; however, Site A was covered largely by wormseed and hemp nettle, which were short in both sites. The dominance of these species in Site A, compared to Site B, may be related to the higher P levels in Site A. It may also suggest that Site A has been more recently disturbed, perhaps by fires; thus, the taller pioneer species have yet to colonize Site A.

\subsection{Potential Productivity of Garden Area}

\subsubsection{Soil Texture}

The ideal soil texture class for agriculture is a loam (40\% sand, $40 \%$ silt, and $20 \%$ clay), allowing for optimal aeration, drainage and root movement. All soil samples from cultivated sites, Sites A, B, and $\mathrm{C}$, were classified as silt loam (Table 2). Sites A, B, and C had much lower sand content, between $13.3 \%-22.8 \%$, more silt, $55.0 \%-71.3 \%$, and near the optimal proportion of clay, $10.9 \%-20.1 \%$ (Table 2), compared to ideal conditions. Silt is a moderately sized soil, between that of clay and sand, and thus 
would have a moderate effect on soil porosity, drainage, root movement and aeration. However, in contrast to clay, silt has low cohesion and adsorptive capacity [47]; higher proportions of silt in this soil may allow leaching of nutrients. Low sand content in this soil is compensated by a low BD (discussed below), which provides the soil with loam-like drainage [48].

\subsubsection{Soil Fertility (N, P, K, Mg, pH)}

The estimated range of IN was at most 140-440 ppm for the proposed garden area, much higher than the recommended fertilizer additions of 17.5-100 ppm (Table 3). Excessive levels of mineralized $\mathrm{N}$ are hazardous in high-input agricultural systems where $\mathrm{N}$ may leach into groundwater, causing eutrophication of water bodies or contamination of potable water sources [49]. However, hazardous levels of mineralized $\mathrm{N}$ are not probable in the study sites, considering that agricultural production halted about forty years ago and that $\mathrm{N}$ levels were found to be much higher in the undisturbed forests of Fort Albany than in the cultivated areas of Fort Albany [2]. The estimated IN values may be much higher than the optimum $\mathrm{N}$-fertilizer values for several reasons. First, it is likely that these soils have more than $95 \%$ of their $\mathrm{N}$ tied up as organic nitrogen $(\mathrm{ON})$, and less than $5 \%$ available IN, because soils of subarctic forests have shown slower decomposition of SOM and lower mineralization of $\mathrm{N}$ due to low temperatures [50,51]. Nutrient mineralization can be further retarded by the high saturation of these soils [52]. Secondly, the $\mathrm{N}$-fertilizer values were reported as a mass $(\mathrm{kg} / \mathrm{ha})$ and converted to a volume (ppm), while, the measured $\mathrm{N}$ values were initially reported as a mass ( $\%$ dry) and converted volume (ppm). Inaccuracies may have resulted during conversion, because different soils have different bulk densities (mass per volume). Third, N-fertilizer values are additions to soil that presumably already contains some mineralized N. Thus, these findings should be treated as loose estimates of "optimum $\mathrm{N}$ levels". With these considerations, the results suggest that usable $\mathrm{N}$ in all three sites is likely near that of "optimum N levels" for diverse crop production, or that excessive amounts of $\mathrm{N}$ are stored as SOM. If too much of the soil $\mathrm{N}$ is tied up in the organic form, it may create deficiencies and causes poor plant yields [37].

The entire range of inorganic P levels in cultivated sites, 7.6-27 ppm, was less than the optimal range of inorganic $\mathrm{P}, 35-70 \mathrm{ppm}$ (Table 2). Low levels of $\mathrm{P}$ are common as $\mathrm{P}$ is the second most highly deficient plant nutrient [33,37]. Cold, wet springs often retard $\mathrm{P}$ absorption [37] and $\mathrm{P}$ mineralization is reduced in cold climate regions [51], making low $\mathrm{P}$ levels in these study sites particularly challenging.

The supply of available soil $\mathrm{K}$ is often small relative to most plant's needs [37]. Such was the case for the proposed garden area, where even maximum exchangeable $\mathrm{K}$ levels (50, 49, and 38 ppm for Sites A, B, and C, respectively) were much lower than the "optimal" range of exchangeable K levels (70-200 ppm) (Table 2). Insufficient exchangeable K reduces plant growth and crop quality [48]. Low clay content, found in about half of the samples, offers fewer exchange sites for K (Table 2) and may be a problem for $\mathrm{K}$ availability.

Mean Mg levels for all sites more than doubled the upper limit of the optimum range of $\mathrm{Mg}$ levels (Table 2). But no negative consequences of excessive Mg could be found in the literature; thus, $\mathrm{Mg}$ levels in the proposed garden sites appear to be more than sufficient. 
The mean soil $\mathrm{pH}$ in the proposed garden area for each site was slightly higher than the optimal of 7 (Table 2), though most crops grow well between 5.5 and 8.5 [37]. However, maximum efficiency of P occurs in soils with a pH between 6 and 7; while, a pH of 6-6.5 is ideal for $\mathrm{K}$ uptake [37]. Therefore, soil $\mathrm{pH}$ in the proposed garden area is likely slightly higher than optimal, considering low $\mathrm{P}$ and $\mathrm{K}$ levels, but sufficient for a successful mixed garden.

For good plant growth, BD should be below $1.4 \mathrm{~g} / \mathrm{cm}^{3}$ for clays and $1.6 \mathrm{~g} / \mathrm{cm}^{3}$ for sands [37]. The entire range of BD values for each site were below these limits (Table 3). These low BD levels create sufficient pore space to allow penetration of tiny crop roots and movement of air, water and soluble nutrients [37]. If BD is too low, however, it could allow too much leaching of soluble nutrients [33]. A low BD is common in fine-textured soils like silt loams, especially those with higher organic matter, because pores exist both between and within the granules [47]. While cultivated loam soils tend to have an average BD of about $1.1 \mathrm{~g} / \mathrm{cm}^{3}$ to $1.4 \mathrm{~g} / \mathrm{cm}^{3}$, greenhouse potting mixtures support plant growth with BDs as low as $0.1 \mathrm{~g} / \mathrm{cm}^{3}$ to $0.4 \mathrm{~g} / \mathrm{cm}^{3}$ [37]. The range of BD values for all sites within the proposed garden area falls between that of loose potting mixtures and cultivated loams; the proposed garden area has suitable levels of BD for crop cultivation.

Natural soils of the James Bay Region below the tree line are very high in SOM [53]. A critical level of SOM for a given soil can be calculated as soil structural integrity ("s"), based on percent SOM, silt and clay. All sites had s values well above the critical value of 9 (Table 3) indicating that soils have sufficient amounts of organic matter to maintain soil structure [33]. Despite 40 years of cultivation by the Mission and the resulting significant losses of SOM [2], the farmed area has relatively high levels of SOM. For now, the area is capable of supporting further cultivation without compromising soil structure and other functions of SOM, including regulation of nutrient availability, acidity, water-holding capacity, and provision of substrate for biota [33].

High levels of SOC relative to ON can reduce SOM mineralization and nutrient availability [40]. A sufficiently low $\mathrm{C}: \mathrm{N}$ ratio for $\mathrm{SOM}$ ensures that mineral $\mathrm{N}$ is produced in excess of the $\mathrm{N}$ needs of bacteria involved in the mineralization process [40]. The estimated mean C:N of substrates for all sites (Table 3) were optimal [40], leaving sufficient mineral $\mathrm{N}$ for plant needs.

Hussack [41], a certified Crop Advisor from Clark Agri Service Inc. of Wellandport, Ontario, estimated that the ideal soil moisture for crop production in silt loam soils is around $40 \%-45 \%$, but explained that optimal soil moisture is highly dependent on environmental conditions, particularly soil type. With a mean, soil-water content (SM) of $92.22 \%, 87.52 \%$, and $94.46 \%$, for Sites A, B, and C (Table 3), competition by trees for soil water does not appear to be of concern in the proposed agroforestry sites. SOM increases infiltration capacity and retains 20 times its weight in water [48] and silt loams have the highest water-holding capacity (maximal amount of water useful to plants), partially accounting for high SM content. Soil moisture is highly spatially and temporally variable [54], making the one-time sample very limited in characterizing moisture content within these sites throughout the growing season.

Overall, soil conditions in three sites are sufficient for use as long-term agroforestry study plots, though site modifications may be necessary to increase $\mathrm{K}$ and P levels, release stored nutrients, and reduce soil moisture. 


\section{Conclusions}

Introduction of Agroforestry test plots in FAFN is feasible as a means to explore subarctic agroforestry as a food security intervention strategy in remote First Nations communities. Agroforestry test plots, control plot and soil sampling design were developed to compare an Agroforestry system, with homegarden, shelterbelt and intercropping components, to a conventional agricultural system with no tree component; these systems can be assessed based on ability to produce diverse foods, protect crops from harsh climate, increase yield, and maintain soil fertility, consistent soil moisture and soil organic matter, in a subarctic environment. Introduction of three gardens, two AFCG test plots and one "no tree" test plot, in the area proposed by the community [2] is feasible and currently in progress; however, a few modifications were necessary to prepare the sites for long-term studies.

\subsection{Recommendations for Agroforestry Community Gardens in Fort Albany}

Site modifications have the potential to enhance the fertility and longevity of the agricultural area: additions of peat from the forest; tillage of the garden area; and enhancement of drainage ditches. The forest's organic soils are recommended for use as an inexpensive, local soil amendment for the test plots and future personal gardens, particularly as harvest increases and soil nutrients decrease over time. Previous studies found that forests surrounding Fort Albany had slightly lower pH, higher sand, higher clay and lower silt [2], making these forest soils closer to optimal conditions. According to Brady and Weil [47], soil texture can be altered by mixing it with another soil of a different textural class. Addition of forest soils to previously cultivated sites can improve drainage with higher proportions of sand and yet improve nutrient adsorption of $\mathrm{P}$ and $\mathrm{K}$ and reduce nutrient loss from drainage, through increased proportions of clay. Low $\mathrm{K}$ and $\mathrm{P}$ in the proposed garden area may be attributed to high silt content, low BD and over-saturated soils. To optimize P uptake, additions of fresh organic material in the soil can release $\mathrm{P}$ as it decomposes, and mitigate $\mathrm{P}$ fixation to insoluble forms [37]; however, Schroth and Sinclair [33] suggest that P fertilizer is necessary for permanent agriculture.

Dry soil amendments from the forest will need to be tilled into the garden plots to increase decomposition of SOM and nutrient availability to plants. Northern ecosystems are known to have low rates of nitrogen mineralization due to low temperatures and short growing seasons [55,56]; natural SOM decomposition in the gardens may be too slow to support mixed garden produce after several years of harvest when available nutrients are removed. Tillage of organic soils at the beginning of the season, however, can provoke nutrient release before the crops are mature enough to absorb them [33]. Since nutrient release is faster from soil incorporated materials rather than surface applied [33], it is recommended that some of the soil amendments are tilled into the garden site prior to planting and that more are added to the surface once crops begin to mature. While tillage of subarctic soils will increase release of atmospheric carbon [17], assisted mineralization of forest soil amendments is likely necessary for optimal crop production; high productivity of local foods will reduce high carbon emissions associated with food imports from the south, far outweighing carbon release from tillage.

Tillage may also be a strategy to increase BD and reduce SOM $[47,48]$, thereby reducing nutrient loss and risk of crop failure from over-saturated soils. Current levels of BD and SOM in the proposed 
garden site suggest that soil structural integrity can be maintained for many years. Monitoring of BD and the "s" value (soil structure) over long-term studies will ensure that optimal BD and SOM levels are maintained at suitable levels. Inclusion of the tree component and lack of large machinery use in AFCGs should assist low BD and high SOM maintenance.

Initiation of crop rotation in the community gardens is recommended after the first year of cropping due to benefits of weed and disease control [57,58], and the presence of highly competitive weeds found in the proposed garden area. Weeds that rapidly spread vegetatively, such as, creeping bentgrass and Canada thistle $[43,45]$, may be controlled by tillage to break up the perennial roots. Further control measures for weeds and other pests will need to be explored during the first few years of cropping, as major pests are identified.

Without proper management of soil moisture in the test plots, excessive water in the crop area is predicted to reduce aeration, retard microbial activity and growth of most plants, and cause loss of nutrients from surface runoff, and leaching to lower horizons [47,59]. Deepening of drainage ditches within the tree rows, as well as at the top and bottom of the plots, may be necessary to assist the willows in drawing moisture from the crop area. The addition of drainage ditches in the no tree plot will be necessary.

\subsection{Feasibility of AFCGs in Other Northern Communities}

Soil and vegetative management recommendations of the present study may not be directly applicable to other subarctic First Nations, particularly those that lack a history of settlement and land management by the Mission; decades of manure application and tillage converted boreal forest soils into present conditions of the proposed garden area of Fort Albany. However, Spiegelaar and Tsuji [2] report that in the Fort Albany area, undisturbed forest soil fertility and texture are conducive to optimal crop production, with proper tillage and drainage. Thus, the implementation of AFCGs in undisturbed areas of the boreal subarctic is feasible and can be expected to become increasingly viable with warming climate and subsequently higher soil nutrient availability [12].

Local areas of subarctic forests can be partially cleared as to make use of existing trees n AFCGs, maintaining natural resilience and adaptability. Tree species and agroforestry design in northern communities will depend on the needs of the area based on local microclimate, soil conditions, cultural and socioeconomic factors, as well as wildlife and carbon sequestration services. With up to 500 species of willow worldwide, predominantly in temperate and arctic zones [60], use of willow in other remote communities is recommended; these willow varieties are adapted to a broad range of climates and site conditions, are easily propagated from cuttings and have a rapid growth rate [60].

Lastly, relatively, large-scale introduction of agroforestry systems with both native and conventional species to remote First Nations may complement traditional Aboriginal harvest and partially mitigate the dependence on petroleum-based imports. AFCGs may transcend standards of food security and establish greater food sovereignty; a culturally appropriate approach to food security that represents Aboriginal/Indigenous food systems, honors sacredness, maintains traditional food strategies and liberates the community from dependence on corporate food producers and distributers [2].

Historically, the traditional values in Fort Albany of environmental stewardship, respect for nature and taking from nature only what is needed [2] allowed for an adaptive and sustainable food system. 
AFCGs may provide a space where these values can be applied as a means to regain a resilient food system within a sedentary community that is challenged by environmental and cultural change. With implementation of long-term AFCG study sites in FAFN, we hope to further explore this possibility and continually evaluate social, ecological, cultural and spiritual benefits of local agroforestry in a remote indigenous community from the perspective of the community members themselves.

\section{Acknowledgements}

We would like to thank Chief and Council of Fort Albany First Nation, the community of Fort Albany First Nation, NSERC, SSHRC and CIHR, for their participation and support in this research.

\section{Conflicts of Interest}

The authors declare no conflict of interest.

\section{References}

1. Honigmann, J. Foodways in a Muskeg Community: An Anthropological Report on the Attawapiskat Indians; Northern Co-ordination and Research Centre, Department of Northern Affairs and National Resources: Ottawa, Canada, 1961; pp. 137-142.

2. Spiegelaar, N.F.; Tsuji, L.J. Impact of Euro-Canadian agrarian practices: In search of sustainable import-substitution strategies to enhance food security in subarctic Ontario, Canada. Available online: http://rrh.org.au (accessed on 8 May 2013).

3. Gates, A.; Hanning, R.M.; Gates, M.; Isogai, A.; Metatawabin, J.; Tsuji, L.J. A school nutrition program improves vegetable and fruit knowledge, preferences, and exposure in First Nation youth. Open Nut. J. 2011, 5, 22-27.

4. Gates, A.; Hanning, R.M.; Gates, M.; Skinner, K.; Martin, I.D.; Tsuji, L.J. Vegetable and fruit intakes of on-reserve schoolchildren compared to Canadian averages and current recommendations. Int. J. Environ. Res. Public Health 2012, 9, 1379-1397.

5. Gates, A.; Hanning, R.M.; Gates, M.; McCarthy, D.; Tsuji, L.J. Inadequate nutrient intakes in youth of a remote First nation community: Challenges and the need for sustainable changes in program and policy. ISRN Pub. Health 2012, doi:10.5402/2012/504168.

6. Gates, M.; Hanning, R.; Gates, M.; McCarthy, D.; Tsuji, L.J. Assessing the impact of pilot school snack programs on milk and alternatives intake in two remote First Nations communities in northern Ontario, Canada. J. Sch. Health 2013, 82, 69-76.

7. Tsuji, L.; Nieboer, E. A question of sustainability in Cree harvesting practices: The seasons, technological and cultural changes in the western James Bay region of northern Ontario, Canada. Can. J. Native Stud. 1999, 19, 169-192.

8. Skinner, K.; Hanning, R.M.; Tsuji, L.J. Barriers and supports for healthy eating and physical activity for first nation youths in Northern Canada. Int. J. Circumpolar Health 2006, 65, 148-161.

9. Bellows, A.; Hamm, H. Local autonomy and sustainable development: testing import substitution in localizing food systems. Agric. Hum. Values 2001, 18, 271-284.

10. Polack, R.; Wood, S.; Bradley, E. Fossil fuels and food security: Analysis and recommendations 
for community organizers. J. Commun. Pract. 2008, 16, 359-374.

11. Indian and Northern Affairs Canada (INAC). Nutrition and Food Security in Fort Severn, Ontario. Available online: http://dsp-psd.pwgsc.gc.ca/Collection/R2-350-2004E.pdf (accessed on 12 May 2013).

12. Shuur, E.; Bockheim, J.; Canadell, J.; Euskirchen, E.; Field, C.; Goryachkin, S.; Hagemann, S.; Kuhry, P.; Lafleur, P.; Lee, H.; et al. Vulnerability of permafrost carbon to climate change: Implications for the global carbon cycle. BioSci 2008, 58, 701-714.

13. Oelbermann, M.; English, M.; Schiff, S. Evaluating carbon dynamics and microbial activity in arctic soils under warmer temperature. Can. J. Soil Sci. 2008, 88, 31-44.

14. Guyot, M.; Dickson, C.; Paci, C.; Furgal, C.; Chan, H. Local observations of climate change and impacts on traditional food security in two northern aboriginal communities. Int. J. Circumpolar Health 2006, 65, 403-415.

15. Morrison, D. Working Group on Indigenous Food Sovereignty Final Activity Report. Available online: http://www.indigenousfoodsystems.org/content/bc-food-systems-network-working-groupindigenous-food-sovereignty-final-report (accessed on 23 June 2013).

16. Robertson, G. Abatement of Nitrous Oxide, Methane, and the other non- $\mathrm{CO}_{2}$ Greenhouse Gases: The Need for a Systems Approach. In The Global Carbon Cycle: Integrating Humans, Climate and the Natural World; Field, C., Raupach, M., Eds.; Island Press: Washington, DC, USA, 2004; pp. 493-506.

17. Gordon, A.; Newman, S. Temperate Agroforestry Systems; CAB International: Cambridge, MA, USA, 1997.

18. Young, A. Agroforestry for Soil Management; CAB International: Wallingford, UK, 1997.

19. Statistics Canada. Population Projections by Aboriginal Identity in Canada, 2006-2011; Government of Canada: Ottawa, Canada, 2011.

20. Vogl, C.; Vogl-Lukasser, B.; Puri, R. Tools and methods for data collection in ethnobotanical studies of homegardens. Field Methods 2004, 16, 285-306.

21. Huai, H.; Hamilton, A. Characteristics and functions of traditional homegardens: A review. Front. Biol. Chin. 2009, 4, 151-157.

22. Ninez, V. Household gardens: Theoretical and policy considerations. Agric. Syst. 1987, 23, 167-186.

23. Boncodin, R.; Campilan, D.; Prain, G. Dynamics in Tropical Homegardens. Available online: http://www.ruaf.org/node/110 (accessed on 26 March 2013).

24. Food and Agricultural Association (FAO). Improving Nutrition through Home Gardening. Available online: http://www.fao.org/ag/AGN/nutrition/household_gardens_en.stm (accessed on 20 March 2013).

25. Quinkenstein, A.; Wöllecke, J.; Böhm, C.; Grünewald, H.; Freese, D.; Schneider, B.; Hüttl, R. Ecological benefits of the alley cropping agroforestry system in sensitive regions of Europe. Environ. Sci. Policy 2009, 12, 1112-1121.

26. Kumar, G.; Murkute, A.; Gupta, S.; Singh, S. Carbon sequestration with special reference to agroforestry in cold deserts of Ladakh. Curr. Sci. 2009, 97, 1063-1068.

27. Long, A.; Nair, R. Trees outside forests: Agro-, community, and urban forestry. New For. 1999, 17, 145-174.

28. Hanson, H.C. Muskeg as sharp-tailed grouse habitat. Wilson Bull. 1953, 65, 235-241. 
29. Abraham, K.; Keedy, C. The Hudson Bay Lowland. In World's Largest Wetlands: Ecology and Conservation; Fraser, L.H., Keddy, P.A., Eds.; Cambridge University Press: Cambridge, UK, 2005; pp. 148-188.

30. Hori, Y.; Tam, B.; Gough, W.A.; Ho-Foong, E.; Karagatzides, E.; Liberda, E.; Tsuji, L.J. The use of traditional environmental knowledge to assess the impact of climate change on subsistence fishing in the james bay region of Northern Ontario, Canada. Available online: http://www.rrh.org.au/publishedarticles/article_print_1878.pdf (accessed on 22 March 2012).

31. Fernandes, E.; Nair, P. An evaluation of the structure and function of homegardens. Agric. Sci. 1986, 21, 279-310.

32. Association for Temperate Agroforestry (AFTA). What is Agroforestry? Available online: http://www.aftaweb.org/ (accessed on 26 March 2013).

33. Schroth, G.; Sinclair, F. Trees, Crops and Soil Fertility: Concepts and Research Methods; CAB International Publishing: Cambridge, MA, USA, 2003.

34. Anderson, J.; Ingram, J. Tropical Soil Biology and Fertility: A Handbook of Methods; CAB International: Cambridge, MA, USA, 1998.

35. Carter, M.; Gregorich, E. Soil Sampling and Methods of Analysis, 2nd ed.; Taylor and Francis Group: Boca Raton, FL, USA, 2008.

36. Ryan, J; Estefan, G.; Rashid, A. Soil and Plant Analysis Laboratory Manual, 2nd ed.; International Center for Agricultural Research in the Dry Areas (ICARDA) and the National Agricultural Research Center (NARC); ICARDA: Aleppo, Syria, 2001.

37. Gardiner, D.; Miller, R. Soils in Our Environment; Pearson Education, Inc.: Upper Saddle River, NJ, USA, 2008.

38. Cain, M.L.; Subler, S.; Evans, J.P.; Fortin, M.-J. Sampling spatial and temporal variation in soil nitrogen availability. Oecol 1998, 118, 397-404.

39. Agriculture Analytical Services Lab of Penn State University (AASL). Soil Test Recommendations for Commercial Vegetables. Available online: http://www.aasl.psu.edu/ Veg\%20Recs_page.htm (accessed on 12 August 2013).

40. Foth, H.; Ellis, B. Soil Fertility; CRC Press: Boca Raton, FL, USA, 1997.

41. Hussack, J. Crop Advisor, Clark Agri Services Inc., Wellandport, Canada. Personal Communication, 23 February 2011.

42. Chmielewski, J.; Semple, J. The biology of Canadian weeds. 113. Symphyotrichum. lanceolatum (Wild.) Nesom (Aster lanceolatus Willd.) and S. lateriflorum (L.) Löve \& Löve (Aster lateriflorus (L.) Britt.). Can. J. Plant Sci. 2001, 81, 829-849.

43. Government of Saskatchewan. Canada Thistle and its Control. Available online: http://www.agriculture.gov.sk.ca/Canada_Thistle_Control (accessed on 19 March 2013).

44. Ontario Ministry of Agriculture, Food and Rural Affairs (OMAFRA). Ontario Weeds: Wormseed mustard. Available online: http://www.omafra.gov.on.ca/english/crops/facts/ontweeds/wormseed mustard.htm (accessed on 19 March 2013).

45. United States Department of Agriculture: Forest Service Fire Effects Information System (USDA). Index of Species Information: Agrostis Stolinifera. Available online: http://www.fs.fed.us/database/feis/plants/graminoid/agrsto/all.html (accessed on 19 March 2013).

46. United States Department of Agriculture: Natural Resource Conservation Service (USDA). Plant 
Database. Available online: http://plants.usda.gov/java/ (accessed on 19 March 2013).

47. Brady, N.; Weil, R. Elements of the Nature and Properties of Soils; Prentice-Hall, Inc.: Upper Saddle River, NJ, USA, 2000.

48. Havlin, J.; Beaton, J.; Tisdale, S.; Nelson, W. Soil Fertility and Fertilizers: An Introduction to Nutrient Management, 7th ed.; Pearson Education, Inc.: Upper Saddle River, NJ, USA, 2005.

49. Spiertz, J. Nitrogen, Sustainable Agriculture and Food Security: A review. Agron. Sustain. Dev. 2010, 30, 34-55.

50. Chapin, S.; Vitousek, P.; van Cleve, K. The nature of nutrient limitation in plant communities. Am. Nat. 1986, 127, 48-58.

51. Smith, C.; Munson, A.; Coyea, M. Nitrogen and phosphorus release from humus and mineral soil under black spruce forests in central quebec. Soil Biol. Biochem. 1998, 30, 1491-1500.

52. Rodriguez-Gonzaleza, P.; Stella, J.; Campeloc, F.; Ferreiraa, M.; Albuquerquea, A. Subsidy or stress? Tree structure and growth in wetland forests along a hydrological gradient in Southern Europe. For. Ecol. Manag. 2010, 259, 2015-2025.

53. Minister of Supply and Services Canada (MSSC). A National Ecological Framework for Canada: Hudson Plains Ecozone and James Bay Lowland; Minister of Supply and Services Canada: Ottawa, Canada, 1996.

54. Western, A.; Grayson, R.; Blöschl, G. Scaling of soil moisture: A hydrologic perspective. Annu. Rev. Earth Plant Sci. 2002, 30, 149-180.

55. Flanagan, P.; van Cleve, K. Nutrient cycling in relation to decomposition and organic-matter quality in taiga ecosystems. Can. J. For. Res. 1983, 13, 795-817.

56. Moore, T. Litter decomposition in a Subarctic Spruce-Lichen Woodland, Eastern Canada. Ecology 1984, 65, 299-308.

57. Wright, R. Evaluation of crop rotation for control of colorado potato beetles (Coleoptera: Chrysomelidae) in commercial potato fields on long island. J. Econ. Entomol. 1984, 77, 1254-1259.

58. Liebman, M.; Dyck, E. Crop Rotation and Intercropping Strategies for Weed Management. Ecol. Appl. 1993, 3, 92-122.

59. Turtola, E.; Paajanen, A. Influence of improved subsurface drainage on phosphorus losses and nitrogen leaching from a heavy clay soil. Agric. Water Manag. 1995, 28, 295-310.

60. Kuzovkina, Y.; Volk, T. The characterization of willow (Salix L.) varieties for use in ecological engineering applications: Co-Ordination of structure, function and autoecology. Ecol. Eng. 2009, $35,1178-1189$.

(C) 2013 by the authors; licensee MDPI, Basel, Switzerland. This article is an open access article distributed under the terms and conditions of the Creative Commons Attribution license (http://creativecommons.org/licenses/by/3.0/). 